\title{
SOME TECHNOLOGICAL PROPERTIES OF LAMINATED VENEER LUMBER PRODUCED WITH FAST-GROWING Poplar AND Eucalyptus
}

\author{
Bekir Cihad Bal ${ }^{1, \$}$
}

\begin{abstract}
Fast-growing tree species are important due to their short growth time before they are harvested. Both the Poplar and Eucalyptus species are fast-growing trees. These two species have been cultivated in many parts of the world, and they are used in several ways, including in the pulp and paper industry, as wood-based panels, and as structural composite lumber. In this study, laminated veneer lumbers were produced using different combinations of Poplar (Populus x euramericana I-214) and Eucalyptus (Eucalyptus grandis) veneers. Some physical and mechanical properties, including density, thickness swelling, water absorption, modulus of elasticity, modulus of rupture, impact bending, and bonding performance were investigated. According to the test data that were obtained, the mechanical properties of laminated veneer lumbers produced with Eucalyptus were greater than those of laminated veneer lumbers produced with Poplar. When the two were combined and Eucalyptus was used as the top and bottom plies, the mechanical properties also were better than those of Poplar laminated veneer lumbers. As a result, it can be said that both Poplar and Eucalyptus veneers can be used to produce laminated veneer lumbers, and Poplar laminated veneer lumbers can be reinforced with Eucalyptus veneers.
\end{abstract}

Keywords: Eucalyptus grandis, physical properties, mechanical properties, Populus $x$ euramericana, reinforcement.

\section{INTRODUCTION}

Some trees grow faster than other trees, and these trees are named fast-growing trees. The fastgrowing trees include Eucalyptus, Acacia, Pinus, and Poplar trees, and the mean annual increment of these species is in the range of 5-40 $\mathrm{m}^{3} /$ ha/year (Cossalter and Pye-Smith 2003).

Naturally-grown forests are decreasing enormously due to the extensive use of wood and the rapid growth of the population (Anonym 2006). Fast-growing tree plantations are being established in many parts of the world to overcome the shortage of wood. Poplar, Pinus, and Eucalyptus plantations have been established in many countries due to their advantages of short production time and low cost.

Plantations of fast-growing trees are being used increasingly for the commercial production of reconstituted products, such as hardboard, particleboard, medium density fiber board (MDF), oriented strand board (OSB), and laminate strand lumber (LSL) (Cossalter and Pye-Smith, 2003). Another commercial, wood-based product is LVL. LVL is manufactured from softwood species and lowto-medium density (290-690 kg/m³) hardwood species of trees. For example, Populus tremuloides,

${ }^{1}$ Kahramanmaraş Sütçü İmam University, Faculty of Forestry, Department of Forest Industry Engineering, Kahramanmaraş. Turkey.

•Corresponding author: bcbal@hotmail.com

Received: 17.09.2015 Accepted: 15.03.2016 
Populus balsmifera, Liriodendron tulipifera, Acacia mangium, Gmelina arborea, Albizia falcata, and some Eucalyptus species have been used or tested for use in the manufacture of LVL (Ozarska 1999). LVL is a structural material, and it is used extensively in the construction of residential and commercial buildings in the U.S. and Canada. It has been reported that about $29 \%$ of all LVL is used in I-beam flanges, while $64 \%$ is used as heavy-duty beams and headers over windows and doors (Anonymous 2009).

In some previous studies, experiments have been conducted with some of the fast-growing species of trees that are used extensively to manufacture veneer-based composite materials. For example, some researchers have investigated the fast-growing species of hybrid Poplar (Baldassino et al. 1998, Bao et al. 2001) and Eucalyptus (Dias and Lahr 2004, Iwakır1 2006, Júnior et al. 2009, Saviana et al. 2009, Bal and Bektaş 2012a, b). In addition, in some previous studies, it was stated that Eucalyptus LVL has mechanical properties that are superior to those of Poplar LVL (Bal and Bektaş 2012a, b). But no previous study has investigated the characteristics of a combination LVL made of Eucalyptus (Eucalyptus grandis) and Poplar (Populus x euramericana I-214). The use of veneers made of fastgrowing Eucalyptus and Poplar trees in different combinations to produce LVL can provide some significant benefits, such as low cost and better performance. Thus, the main aim of this study was to evaluate selected physical and mechanical properties of Eucalyptus LVL, Poplar LVL, and LVLs made by combining the veneers of these two fast-growing species.

\section{MATERIALS AND METHODS}

\section{Materials}

Eucalyptus (Eucalyptus grandis W. Hill ex Maiden) logs were obtained from the Karabucak-Tarsus region in Turkey, and the Poplar (Populus x euramericana I-214) logs were obtained from Karabük region. The Eucalyptus logs were steamed at $80^{\circ} \mathrm{C}$ for $15 \mathrm{~h}$. The Poplar logs were not steamed. Then, 3 -mm thick rotary-peeled veneers were obtained from the logs and dried in a plywood factory until the moisture content was $7 \pm 1 \%$. The veneers were classified visually based on the sizes of the defects that were observed.

Phenol formaldehyde (PF) adhesive (Polifen 47) was obtained from Polisan A.Ș. to produce the LVL boards. Some properties of the PF adhesive were as follows: specific gravity of 1.2 at $20^{\circ} \mathrm{C}$; solid content of $47 \pm 1 \%$, pH of $11-13$, viscosity of $250-500 \mathrm{Cp}$ at $20^{\circ} \mathrm{C}$, and gel time of $10-20 \mathrm{~min}$ at 105 ${ }^{\circ} \mathrm{C}$. No additives or fillers were used with the PF adhesive.

\section{LVL production}

A manual roller was used to apply the adhesive to the loose surfaces of the veneer in the amount of $200 \mathrm{~g} / \mathrm{m}^{2}$. After the adhesive was applied, the veneer sheets pressed together parallel to each other, with seven veneer sheets with a nominal size of $600 \times 600 \times 3 \mathrm{~mm}^{3}$ (length $\times$ width $\times$ thickness) for each LVL board. The loose side of the veneer was placed towards the center of the boards. Four LVL boards were produced for each group. The LVL boards were pressed in a laboratory press for $24 \mathrm{~min}$. Because Poplar wood has a lower density than Eucalyptus, the press pressures for group A, B, C, and D were $7,7,7$, and $12 \mathrm{~kg} / \mathrm{cm}^{2}$, respectively. After pressing, the LVL boards were stored for five days to cure. Then, samples were cut from the boards for use in the physical and mechanical tests. For each test, the same numbers of test samples were cut from each board to ensure homogeneity. In addition, edgewise and flatwise test samples for bending tests (as can be seen Figure 1) and impact tests were prepared side by side for each group. Figure 1 shows the four different test groups. The first group contained only poplar veneers. The second group had two plies (top and bottom surfaces) of Eucalyptus veneers and five plies of Poplar veneers. The third group contained four plies of Eucalyptus (two on the top surface and two on the bottom surface) and three plies of Poplar veneers. The fourth group only contained Eucalyptus veneers. 

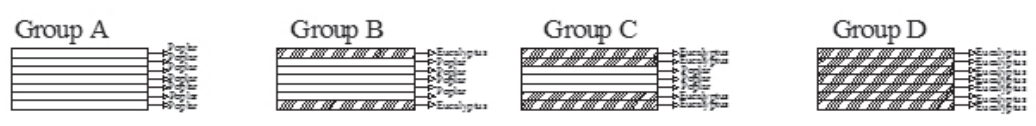

Figure 1. Combination of LVL boards.

\section{Method}

Tests were conducted according to TS EN 323 and TS EN 317 to determine the air-dried density and the thickness swelling-water absorption, respectively. Before the tests, the samples were conditioned in climatic chamber at $20{ }^{\circ} \mathrm{C}$ and $65 \%$ relative humidity for five weeks.

The three-point bending tests were conducted according to TS EN 310. The width, thickness, and length of the test samples were approximately 20,20 , and $300 \mathrm{~mm}$, respectively. Bending tests were conducted in flatwise and edgewise directions with 15 samples from each of the test groups (Figure 2).
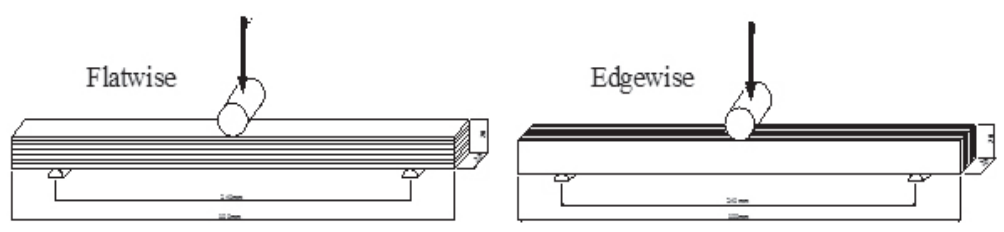

Figure 2. The three-point bending test diagrams in flatwise and edgewise directions.

The tensile-shear strength was tested according to TS EN 314-1 and TS EN 314-2. The thickness, width, and length of the test samples were 20,25 , and $100 \mathrm{~mm}$, respectively. Two 3-mm grooves were cut on either side to a depth of three plies. The glue shearing area was maintained at $25 \times 25 \mathrm{~mm}$, and two tests groups were prepared. Fourteen test samples were prepared for each group. The first group was tested after pre-treatment with cold water for $24 \mathrm{~h}$. The second group underwent pre-treatment with cold water for $24 \mathrm{hr}$ and with boiling water for $4 \mathrm{~h}$, after which the samples were dried in an oven for $20 \mathrm{~h}$ and treated with boiling water again for $4 \mathrm{~h}$. The samples were tested after this process was completed.

Impact bending strength was determined according to TS 2477. Impact bending strength was tested in flatwise and edgewise direction at span to depth ratio was 12 . The width and thickness of test samples were 20 and $20 \mathrm{~mm}$, respectively, and the length was $300 \mathrm{~mm}$. The span length was $240 \mathrm{~mm}$. Impact bending strength was measured on an Amsler pendulum impact test machine.

The compression ratio of the veneer sheets after the press process was also calculated. The dimensions and weights of all of the veneer sheets were measured and their densities were calculated. After the test samples were prepared, they were conditioned in the climatic chamber at $20^{\circ} \mathrm{C}$ and $65 \%$ relative humidity for five weeks. At the end of this period, the dimensions and weights of the samples were measured to calculate the density of the LVL boards. Compression ratio (CR) and densification ratio (DR) was calculated as shown below: 


$$
C R=\frac{\left(T_{V}-T_{B}\right)}{T_{V}}(\%)
$$

where $C R$ is the compression ratio, $T_{V}$ is the thickness of the total veneer $(\mathrm{mm})$, and $T_{B}$ is the thickness of the board (mm).

$$
D R=\frac{\left(D_{B}-D_{V}\right)}{D_{V}}(\%)
$$

where $\mathrm{DR}$ is the densification ratio, $\mathrm{D}_{\mathrm{V}}$ is the density of the veneer $\left(\mathrm{kg} / \mathrm{m}^{3}\right)$, and $\mathrm{D}_{\mathrm{B}}$ is the density of the board $\left(\mathrm{kg} / \mathrm{m}^{3}\right)$.

\section{Statistical Analysis}

The obtained data were analyzed using one-way ANOVA for tested properties $(p=0,05)$ from the SPSS statistical software program, and significant differences between groups were determined by Tukey Multiple Comparison Test $(\alpha=0,05)$.

\section{RESULTS AND DISCUSSION}

\section{Physical properties}

The total thickness of the veneer for each group, the thickness of the LVL board, the compression ratio, the density of the veneer, the density of the LVL board, the densification ratio, thickness swellings, and water absorption percentages are shown in Table 1 . The data in Table 1 indicate that the compression ratio and the densification ratio of group A were the highest, and these values were the lowest for group D. Press pressure affected the compression ratio, i.e., as the press pressure increased, the compression ratio increased. Similar results were reported by Kurt and Cil (2012). However, press pressure and the amounts of adhesive, filler, and additives affected the densification ratio. Therefore, the densification ratios were determined to be greater than the compression ratios for all of the groups. Similar results were reported by other researchers (Bao et al. 2001, Wang and Chui 2012). Another factor that affected the compression ratio and the densification ratio was the density of the wood. At the same press pressure, the compression ratio of lower-density wood was greater than that of higherdensity wood. Although the pressure used for Poplar LVL $\left(7 \mathrm{~kg} / \mathrm{cm}^{2}\right)$ was lower than that used for Eucalyptus LVL $\left(12 \mathrm{~kg} / \mathrm{cm}^{2}\right)$, the density of the Poplar LVL made its compression ratio greater than that of Eucalyptus LVL.

The thickness swellings and water absorption percentages are shown in Table 1. At the end of the $2 \mathrm{~h}$ immersion, the lowest percentages were obtained for the LVLs in group $\mathrm{D}$, and the highest percentages were obtained for the LVLs in group A, and the differences were significant $(p<0,05)$. These percentages for Groups B and C were not significantly different. One reason of this result was the permeability of the veneers, and Poplar veneers are more permeable than Eucalyptus veneers. As a result, the water absorption of Poplar LVL (group A) and Eucalyptus LVL (group D) were 19,7 and $6,7 \%$; respectively and the differences were significant $(\mathrm{p}<0,001)$. There was a positive relationship between thickness swellings and water absorption percentages. Another reason for this result was the 
effect of press pressure on the compression ratio. As the pressure increased, the thickness swelling of the board increased (Özen 1981, Kurt and Cil 2012). However, it was no feasible to separate out the individual effects of permeability and press pressure on thickness swelling. But, after the 24-h immersion, the thickness swelling of group D was greater than that of group A, and the differences were significant $(\mathrm{p}<0,001)$. Water absorption by group $\mathrm{D}$ reached $23 \%$. At the end of this period, the wood fibers of the Eucalyptus test samples were saturated with water, and they swelled in the direction of thickness. The thickness swellings of groups A and D were determined to be approximately 2,1 and 2,6\%, respectively. Eucalyptus LVL swelled more than Poplar LVL, which was expected due to the density of Eucalyptus. It is well known that greater-density wood swells more than lower-density wood. Similar results were reported by other researchers concerning this issue (Uysal 2005, Bal 2013). In addition, veneer drying temperature affects the veneer-water relationships. Concerning this issue, Aydin (2014) studied the effects of veneer drying at high temperature on equilibrium moisture content, and reported that high temperature veneer drying caused a significant decrease in equilibrium moisture content values of plywood produced from Beech, Spruce and Alder veneers.

Table 1. Physical properties of veneers and LVL boards and Tukey results of TS and WA.

\begin{tabular}{|c|c|c|c|c|c|c|c|c|c|c|}
\hline & $\mathrm{T}_{\mathrm{v}}$ & $\mathrm{T}_{\mathrm{B}}$ & $\mathrm{CR}$ & $\mathrm{D}_{\mathrm{v}}$ & $\mathrm{D}_{\mathrm{B}}$ & $\mathrm{DR}$ & $\mathrm{TS}-2$ & $\mathrm{WA}-2$ & $\mathrm{TS}-24$ & $\mathrm{WA}-24$ \\
\hline & $\mathrm{mm}$ & $\mathrm{mm}$ & $\%$ & $\mathrm{~kg} / \mathrm{m}^{3}$ & $\mathrm{~kg} / \mathrm{m}^{3}$ & $\%$ & $\%$ & $\%$ & $\%$ & $\%$ \\
\hline $\begin{array}{c}\text { Group A } \\
\text { 7-ply } \\
\text { Poplar }\end{array}$ & $\begin{array}{c}21,42 \\
(0,02)\end{array}$ & $\begin{array}{c}19,22 \\
(0,14)\end{array}$ & 10,3 & $\begin{array}{c}340 \\
(24)\end{array}$ & $\begin{array}{c}419 \\
(13)\end{array}$ & 23,1 & $\begin{array}{c}1,22 \mathbf{a}^{1} \\
(0,49)^{2}\end{array}$ & $\begin{array}{c}19,69 \mathbf{a} \\
(2,69)\end{array}$ & $\begin{array}{c}2,09 \mathbf{a} \\
(0,25)\end{array}$ & $\begin{array}{c}59,56 \mathbf{a} \\
(3,90)\end{array}$ \\
\hline $\begin{array}{c}\text { Group B } \\
\text { 1E+5P+1E }\end{array}$ & $\begin{array}{c}21,46 \\
(0,03)\end{array}$ & $\begin{array}{c}19,53 \\
(0,20)\end{array}$ & 9,0 & $\begin{array}{c}420 \\
(96)\end{array}$ & $\begin{array}{c}497 \\
(20)\end{array}$ & 18,5 & $\begin{array}{c}1,08 \mathbf{a b} \\
(0,48)\end{array}$ & $\begin{array}{c}14,33 \mathbf{b} \\
(2,29)\end{array}$ & $\begin{array}{c}2,35 \mathbf{b} \\
(0,37)\end{array}$ & $\begin{array}{c}43,14 \mathbf{b} \\
(3,99)\end{array}$ \\
\hline $\begin{array}{c}\text { Group C } \\
\text { 2E+3P+2E }\end{array}$ & $\begin{array}{c}21,15 \\
(0,02)\end{array}$ & $\begin{array}{c}19,63 \\
(0,30)\end{array}$ & 7,2 & $\begin{array}{c}450 \\
(92)\end{array}$ & $\begin{array}{c}523 \\
(26)\end{array}$ & 16,3 & $\begin{array}{c}1,12 \mathbf{a b} \\
(0,21)\end{array}$ & $\begin{array}{c}12,55 \mathbf{b} \\
(2,40)\end{array}$ & $\begin{array}{c}2,44 \mathbf{b} \\
(0,23)\end{array}$ & $\begin{array}{c}36,40 \mathbf{c} \\
(4,01)\end{array}$ \\
\hline $\begin{array}{c}\text { Group D } \\
\text { 7ply Euc, }\end{array}$ & $\begin{array}{c}21,30 \\
(0,03)\end{array}$ & $\begin{array}{c}19,77 \\
(0,35)\end{array}$ & 7,2 & $\begin{array}{c}535 \\
(52)\end{array}$ & $\begin{array}{c}616 \\
(27)\end{array}$ & 15,1 & $\begin{array}{c}0,87 \mathbf{b} \\
(0,37)\end{array}$ & $\begin{array}{c}6,68 \mathbf{c} \\
(1,38)\end{array}$ & $\begin{array}{c}2,59 \mathbf{b} \\
(0,35)\end{array}$ & $\begin{array}{c}23,23 \mathbf{d} \\
(3,60)\end{array}$ \\
\hline
\end{tabular}

Tv: total thickness of the veneer for each group; $\mathrm{T}_{\mathrm{B}}$ : thickness of the LVL board; CR: compression ratio; $\mathrm{D}_{\mathrm{V}}$ : density of the veneer; $\mathrm{D}_{\mathrm{B}}$ : density of the LVL board; DR: densification ratio; TS: thickness swelling; WA: water absorption percentage. ${ }^{1}$ Means followed by the same letter are not significantly different

${ }^{2}$ Standard deviations are shown in parentheses

\section{Mechanical properties}

The mechanical properties, such as modulus of rupture, modulus of elasticity, impact bending strength, and tensile-shear strength are shown in Table 2. Bending strength tests were performed in both the flatwise and edgewise directions. The data in Table 2 show that the MOE and MOR values of group D were the highest, and the values of group A were the lowest for both the flatwise and edgewise directions. The differences between the two groups were statistically significant $(p<0,001)$. The MOE and MOR values of group B were greater than those of group A for both the flatwise and edgewise directions. The differences between groups A and B were significant $(p<0,001)$. The differences between the MOE values were greater than the differences between the MOR values. Group B consisted of two-ply Eucalyptus and 5-ply Poplar veneers. In the bending tests, there were three zones on the test samples, i.e., compression zone, neutral axis, and tension zone. Breaking occurred on the bottom surface of the tension zone and at the subsurface of the samples. When the test was conducted in the flatwise direction, first, the bottom surface of the samples were forced, rupture occurred, and the test 
ended. Therefore, the stronger the bottom surface veneer was, the greater the bending strength became. Eucalyptus grandis veneers have greater bending strength than Poplar veneers (Bal and Bektaş 2012b, 2014). As a result, groups B, C, and D had greater bending strengths than group A. However, in tests conducted in the edgewise direction, all of the veneers acted together as one body. During the test, first, the bottom edges of the veneers ruptured. Then, continuing the test resulted in the rupture of the entire body of the sample. Concerning this issue, Wang and Dai (2005) stated that edgewise MOE and MOR values depended on the MOE value of each constituent veneer sheet, whereas the flatwise bending strength properties were dominated by the MOE values of the face veneers. It is well known situation that wood based composite materials such as structural composite lumbers (SCLs), plywood and OSB have different properties in parallel and perpendicular grain directions. In a previous study, Mendes et al. (2015) studied the properties of OSB panels with veneer inclusion, and noted that the face veneers bonded to surface of OSB panels effect the MOE and MOR values of OSB panels. In addition, Demirkır and Çolakoğlu (2015) reported that lateral nail strength of plywood panels produced from pine veneers was significantly different in perpendicular and parallel directions.

The MOE and MOR values of all groups were greater in the flatwise direction than in the edgewise direction (Table 2). The important reason for this discrepancy was the pressing direction. Similar results were reported by some other researchers (Wang and Dai 2005, Bal and Bektaş 2012a,b, Bal 2014a).

Table 2. Results of MOE, MOR, IB, and TSS.

\begin{tabular}{|c|c|c|c|c|c|c|c|c|}
\hline & MOE & MOR & MOE & MOR & \multicolumn{2}{|c|}{ IB } & \multicolumn{2}{|c|}{ TSS } \\
\hline & \multicolumn{2}{|c|}{ Flatwise } & \multicolumn{2}{|c|}{ Edgewise } & Flatwise & Edgewise & Cold water & $\begin{array}{c}\begin{array}{c}\text { Boiling } \\
\text { water }\end{array}\end{array}$ \\
\hline & \multicolumn{4}{|c|}{$\mathrm{MPa}$} & \multicolumn{2}{|l|}{$\mathrm{kgm} / \mathrm{cm}^{2}$} & \multicolumn{2}{|l|}{$\mathrm{MPa}$} \\
\hline Group A & $\begin{array}{l}5433 \mathbf{a}^{1} \\
(733)^{2}\end{array}$ & $\begin{array}{l}66,1 \mathbf{a} \\
(6,3)\end{array}$ & $\begin{array}{l}4902 \mathbf{a} \\
(334)\end{array}$ & $\begin{array}{l}63,3 \mathbf{a} \\
(4,0)\end{array}$ & $\begin{array}{l}0,30 \mathbf{a} \\
(0,07)\end{array}$ & $\begin{array}{l}0,25 \mathbf{a} \\
(0,05)\end{array}$ & $\begin{array}{l}2,56 \\
(0,36)\end{array}$ & $\begin{array}{l}2,21 \\
(0,31)\end{array}$ \\
\hline Group B & $\begin{array}{l}8842 \mathbf{b} \\
(707)\end{array}$ & $\begin{array}{l}79,2 \mathbf{b} \\
(8,0)\end{array}$ & $\begin{array}{l}6374 b \\
(410)\end{array}$ & $\begin{array}{l}71,0 \mathbf{b} \\
(4,7)\end{array}$ & $\begin{array}{l}0,41 \mathbf{b} \\
(0,08)\end{array}$ & $\begin{array}{l}0,37 \mathbf{b} \\
(0,10)\end{array}$ & & - \\
\hline Group C & $\begin{array}{l}9351 \mathbf{b} \\
(847)\end{array}$ & $\begin{array}{l}85,9 \mathbf{b} \\
(7,9)\end{array}$ & $\begin{array}{l}7069 c \\
(831)\end{array}$ & $\begin{array}{l}82,0 \mathbf{c} \\
(6,0)\end{array}$ & $\begin{array}{l}0,48 \text { bc } \\
(0,13)\end{array}$ & $\begin{array}{l}0,42 \text { bc } \\
(0,08)\end{array}$ & $\begin{array}{l}2,36 \\
(0,59)\end{array}$ & $\begin{array}{l}2,09 \\
(0,61)\end{array}$ \\
\hline Group D & $\begin{array}{l}10554 \mathbf{c} \\
(1306)\end{array}$ & $\begin{array}{l}100,4 \mathbf{c} \\
(13,2)\end{array}$ & $\begin{array}{l}8701 d \\
(744) \\
\end{array}$ & $\begin{array}{l}88,5 \mathbf{d} \\
(8,6)\end{array}$ & $\begin{array}{l}0,52 \mathbf{c} \\
(0,05)\end{array}$ & $\begin{array}{l}0,49 \mathbf{c} \\
(0,07)\end{array}$ & $\begin{array}{l}4,28 \\
(1,47)\end{array}$ & $\begin{array}{l}3,37 \\
(0,59)\end{array}$ \\
\hline $\begin{array}{l}\text { Significance } \\
\text { Level }\end{array}$ & $* * *$ & $* * *$ & $* * *$ & $* * *$ & $* * *$ & $* * *$ & & \\
\hline
\end{tabular}


Figures 3, 4, 5, and 6 show the relationship between MOE and MOR values that were determined. The Figures also present the regression equation and the coefficients of determination $\left(\mathrm{R}^{2}\right)$ between MOE and MOR. The Figures show that the coefficients of determination between MOE and MOR in the edgewise directions were greater than those in the flatwise direction. This discrepancy between the flatwise and edgewise directions resulted from the pressing direction that was used, as stated earlier. Similar reasons were stated concerning this issue by Wang and Dai (2005).

In most structures, such as roof trusses and floor joists, the wooden members are bent edgewise. For specific applications, such as scaffold planks, the flatwise bending values of MOE and MOR are critical (Steffen et al. 1997). For this reason, many researchers have conducted experiments with LVL in both the edgewise and flatwise directions, and the relationship between the MOE and MOR values, or the bending properties and density, were determined. For example, Saviana et al. (2009) tested the bending properties of LVL produced from Eucalyptus grandis and determined relationship between MOE and density at an $\mathrm{R}^{2}$ value of 0,37 .

Table 2 provides the test results of impact bending (shock resistance). The most remarkable result is that the impact bending of Eucalyptus LVL (group D) were double that of the Poplar LVL in both flatwise and edgewise directions. The differences were statistically significant $(\mathrm{p}<0,001)$. The other remarkable result was that the impact bending in the flatwise direction was greater than that in the edgewise direction for all groups. Group B was statistically different from group A. Remarkable increases were obtained using Eucalyptus veneers only. The percentage increases in the flatwise and edgewise directions were 37 and $48 \%$, respectively.

Mechanical properties, such as static bending and impact bending strength, are crucial for loadbearing components. But, LVL produced with poplar and other low density wood species has lower impact bending strength. For this reason, some modification methods have been tried by researchers. For example, Chui et al. (1994) studied the reinforcement of Poplar LVL using the resin impregnation method, and some important results were reported. A similar study was conducted with pine veneer using PF resin (Wang and Chui 2012). In another study, San and Tahir (2003) reinforced low-density veneer LVL using high-density veneer. Similarly, Wong et al. (1996) studied the properties of rubber wood LVL reinforced with Acacia veneers. Another modification method for veneer is the densification process. Gaff and Gasparik (2015) studied densified beech veneers, and they noted that densification of veneers has important effects on their bending properties. Similar results were reported by Bekhta et al. (2009) and Bekhta et al. (2012). Glass fiber fabric also was used to reinforce poplar LVL. Reinforced poplar LVL with glass fiber fabric was produced to obtain more powerful poplar LVL (Yanagawa et al. 1995, Ribeiro et al. 2009, Bal 2014a,b).

Tensile shear strength was tested to evaluate the bonding performance of Poplar-Poplar veneer (group A), Poplar-Eucalyptus veneer (group C), and Eucalyptus-Eucalyptus veneers (group D). It is well known that different types of veneers, especially veneers that have lower and greater densities, may not be bonded very well to each other. Table 2 gives the results of the tensile shear strength tests. The highest bonding performance was obtained for group $\mathrm{D}$, and the lowest was obtained for group C. These results were expected because of the greater density of Eucalyptus veneers. It is well known that the greater the veneer density is, the greater the tensile shear strength is. Similar results were reported by other researhers (Özen 1981, Örs et al. 2002, Hashim et al. 2011, Bal and Bektaş 2014). Group B was not tested for shear strength. All tensile-shear strength results for groups A, C, and D were greater than $1 \mathrm{MPa}$, which is the boundary value according to TS EN 314-2, and this value is deemed to be adequate for requirements in specific usage areas. 

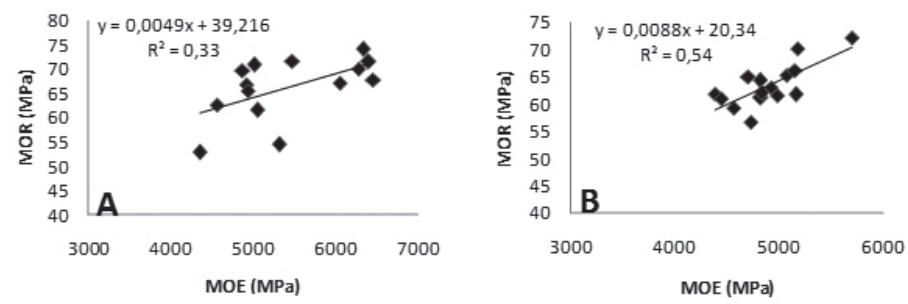

Figure 3. Relationship between MOE and MOR for group A: A, flatwise; B, edgewise.
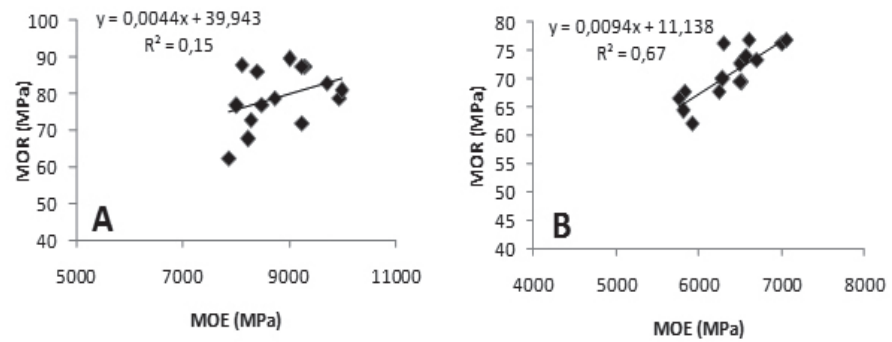

Figure 4. Relationship between MOE and MOR for group B: A, flatwise; B, edgewise.
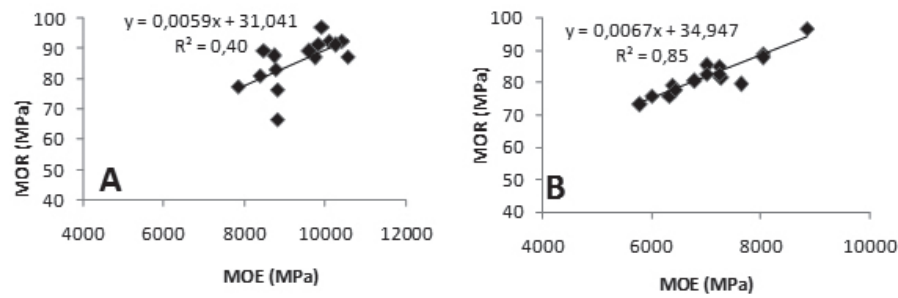

Figure 5. Relationship between MOE and MOR for group C: A, flatwise; B, edgewise.
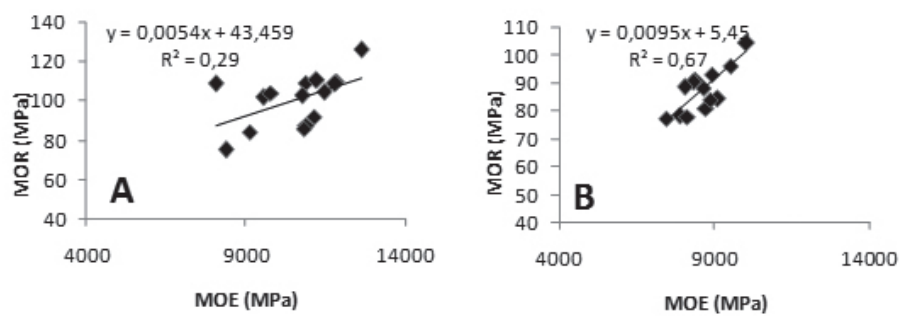

Figure 6. Relationship between MOE and MOR for group D: A, flatwise; B, edgewise. 


\section{CONCLUSIONS}

In this study, some technological properties of LVL produced with poplar and Eucalyptus veneers using PF resin were investigated. Based on the data that were obtained, we reached the following conclusions: The WA of groups with Eucalyptus veneers (groups B, C, and D) were lower than that of the poplar LVL (group A). The mechanical properties of the LVL groups that used Eucalyptus veneers had greater bending properties than poplar LVL (group A). Using only one veneer sheet on the surfaces (group B) increased the mechanical properties of LVL significantly. Therefore, it can be said that poplar LVL can be reinforced with Eucalyptus veneers. Mechanical properties (MOR, MOE, and IB) in the flatwise direction were greater than in the edgewise direction. The most differences between directions were measured for the MOE values. The relationships between MOE and MOR were more powerful in the edgewise direction than in the flatwise direction. The bonding performances of Poplar-Poplar veneers, Poplar-Eucalyptus veneers, and Eucalyptus-Eucalyptus veneers were evaluated according to related European standards. In addition, the utilize poplar and Eucalyptus trees in the production of LVL is an important issue due to their low cost due to their being fast-growing tree species.

\section{REFERENCES}

Anonymous. 2006. Forestry Special Commission Report, $9^{\text {th }}$ Development Plan, DPT, Ankara.

Anonymous. 2009. Forest products annual market review, food and agriculture organization of the united nations, P:139-143 Geneva-Switzerland.

Aydin, I. 2014. Effects of veneer drying at high temperature and chemical treatments on equilibrium moisture content of plywood. Maderas-Cienc Tecnol 16(4):445-452.

Bal, B.C.; Bektaş, I. 2012a. The effects of some factors on the impact bending strength of laminated veneer lumber. BioResources 7:5855-5863.

Bal, B.C.; Bektaş, I. 2012b. The effects of wood species, load direction, and adhesives on bending properties of laminated veneer lumber. BioResources 7:3104-3112.

Bal, B.C. 2013. Okaliptüs, Kayın ve Kavak Soyma Kaplamaları ile Üretilen Tabakalı Kaplama Kerestelerin (TKK) Bazı Fiziksel Özellikleri. Artvin Çoruh Üniversitesi, Orman Fakültesi Derg 14: $25-35$.

Bal, B.C. 2014a. Flexural properties, bonding performance and splitting strength of LVL reinforced with woven glass fiber. Constr Build Mater 51: 9-14.

Bal, B.C. 2014b. Some physical and mechanical properties of reinforced laminated veneer lumber. Constr Build Mater 68: 120-126. 
Bal, B.C.; Bektaş, I. 2014. Some mechanical properties of plywood produced from Eucalyptus, beech, and Poplar veneer. Maderas-Cienc Tecnol 16:99-108.

Baldassino, N.; Zanon, P.; Zanuttini, R. 1998. Determining mechanical properties and main characteristic values of Poplar plywood by medium-sized test pieces. Mater Struct 31:64-67.

Bao, F.; Fu, F.; Choong, E.T.; Hse, C. 2001. Contribution factor of wood properties of three poplar clones to strength of laminated veneer lumber. Wood Fiber Sci 33: 345-352.

Bekhta, P.; Hiziroglu, S.; Shepelyuk, O. 2009. Properties of plywood manufactured from compressed veneer as building material. Mater Des 30: 947-953.

Bekhta, P.; Niemz, P.; Sedliacik, J. 2012. Effect of pre-pressing of veneer on the glueability and properties of veneer-based products. Eur Journal Wood Prod 70(1-3):99-106.

Chui, Y.; Schneider, M.; Zhang, H. 1994. Effects of resin impregnation and process parameters on some properties of poplar LVL. For Prod J 44:74-78.

Cossalter, C.; Pye-Smith, C. 2003. Fast-wood Forestry: Myths and Realities. CIFOR, vol 1, 50p.

Demirkır, C.; Çolakoglu, G. 2015. The effect of grain direction on lateral nail strength and thermal conductivity of structural plywood panels. Maderas-Cienc Tecnol 17 (3):469-478.

Dias, F.M.; Lahr, F.A.R. 2004. Alternative castor oil-based polyurethane adhesive used in the production of plywood. Mater Res 7:413-420.

Gaff, M.; Gasparik, M. 2015. Influence of Densification on Bending Strength of Laminated Beech Wood. BioResources 10:1506-1518.

Hashim, R.; Sarmin, S.N.; Sulaiman, O.; Yusof, L.H.M. 2011. Effects of cold setting adhesives on properties of laminated veneer lumber from oil palm trunks in comparison with rubberwood. Eur Journal Wood Prod 69: 53-61.

Iwakiri, S.; Neto, A.; de Almeida, B.; Biasi, C.; Chies, D.; Guisantes, F.; Franzoni, J.; Rigatto, P.; Bettega, W. 2006. Evaluation of quality of phenolic plywood manufactured from Eucalyptus grandis. Ciência Florest 16:437-443.

Júnior, J.B.G.; Mendes, L.M.; Mendes, R.F.; Mori, F.A. 2009. Plywood boards of Eucalyptus: a case study of species and provenances. Cerne 15:10-18.

Kurt, R.; Cil, M. 2012. Effects of press pressures on glue line thickness and properties of laminated veneer lumber glued with phenol formaldehyde adhesive. BioResources 7: 5346-5354.

Mendes, R. F.; da Silva César, A. A.; Gomes da Silva, M.; Marin Mendes, L.; Guimarães Carvalho, A. 2015. Properties of OSB panels with veneer inclusion. Maderas-Cienc Tecnol 17(4):843856. 351.

Ozarska, B. 1999. A review of the utilisation of hardwoods for LVL. Wood Sci Technol 33: 341- 
Örs, Y.; Çolakoğlu, G.; Aydın, İ.; Çolak, S. 2002. Kayın, okume ve kavak soyma kaplamalarından farklı kombinasyonlar da üretilen kontrplakların bazı teknik özelliklerinin karşılaştırılması. J Polytech 5(3): 257-265.

Özen, R. 1981. Çeşitli Faktörlerin Kontrplağın Fiziksel ve Mekanik Özelliklerine Yaptığı Etkilere İlişkin Araştırmalar. Trabzon.

Ribeiro, A.S.; de Jesus, A.M.P.; Lima, A.M.; Lousada, J.L.C. 2009. Study of strengthening solutions for glued-laminated wood beams of maritime pine wood. Constr Build Mater 23: 2738-2745.

San, H.P.; Tahir, P. 2003. Bending properties of laminated veneer lumber: effect of keruing (Dipterocarpus spp.) reinforcement and cyclic-boil-dry-treatment. XII World For. Congr. Quebec City, CANADA.

Saviana, J.; Sosa, Z.M.; Piter, J. 2009. Bending strength and stiffness of structural laminated veneer lumber manufactured from fast-growing Argentinean Eucalyptus grandis. Maderas-Cienc Tecnol 11:183-190.

Steffen, A.; Johansson, C.J.; Wormuth, E.W. 1997. Study of the relationship between flatwise and edgewise moduli of elasticity of sawn timber as a means to improve mechanical strength grading technology. Holz als Roh- und Werkst 55: 245-253.

TS 2477. 1976. Wood determination of Impact bending strength; Turkish standard Institute, Ankara, Turkey.

TS EN 310. 1999. Wood based panels determination of modulus of elasticity in bending and of bending strenght, TSE, Ankara.

TS EN 317. 1999. Particleboards and fibreboards - Determination of swelling in thickness after immersion in water, TSE. Ankara.

TS EN 323. 1999. Wood based panels-Determination of density. TSE, Ankara.

TS EN 314-1. 1998. Plywood-Bonding quality-Part 1: Test methods. TSE, Ankara.

TS EN 314-2. 1999. Plywood- Bonding quality- Part 2: Requirements. TSE, Ankara.

Uysal, B. 2005. Bonding strength and dimentional stabilityof laminated veneer lumbers manufactured by using different adhesives after the steam test. Int $J$ Adhes Adhes 25: 395-403.

Wang, B.J.; Chui, Y.H. 2012. Manufacturing of LVL using cost-effective resin impregnation and layup technologies. Wood Sci Technol 46: 1043-1059.

Wang, B.J.; Dai, C. 2005. Hot-pressing stress graded aspen veneer for laminated veneer lumber (LVL). Holzforschung 59: 10-17.

Wong, E.D.; Razali, A.K.; Kawai, S. 1996. Properties of rubber wood LVL reinforced with Acacia veneers. Wood research: bulletin of the Wood Research Institute, Kyoto University 83:8-16. 
Yanagawa, Y.; Kawai, S.; Sasaki, H.; Wang, Q.; Kondo, M.; Shirai, F. 1995. Production of laminated veneer lumber with a continuous steam-injection pres, 2. Production and properties of fiberreinforced laminated veneer lumber. Mokuzal Gakkalshı 41: 483-489. 